\title{
Studies on the effect of caffeine on growth and yield parameters in Helianthus annuus L. variety Modern
}

\author{
T Khursheed, MYK Ansari, D Shahab* \\ Cytogenetics and Mutation Breeding Lab, Department of Botany, \\ Aligarh Muslim University, Aligarh-202002, U.P. (INDIA). \\ *Corresponding author: danish18581@yahoo.co.in \\ Cell: $+91-9258537017$
}

\begin{abstract}
In present investigation, the seeds of Helianthus annuus L. variety Modern were treated with nine different concentrations $(0.05 \%, 0.25 \%, 0.50 \%, 0.75 \%, 1.00 \%, 1.25 \%, 1.50 \%, 1.75 \%$ and $2.00 \%)$ of caffeine to raise the $\mathrm{M}_{1}$ generation and the effect of caffeine on seedling height on $30^{\text {th }}$ day of sowing, mature plant height, days to maturity and yield parameters was observed. Generally, the lower doses of caffeine were found stimulatory for the seedling height on $30^{\text {th }}$ day of sowing, mature plant height, days to maturity and 100-seeds weight. While, the number of seeds in treated plants showed a dose dependent increase with the increasing doses of mutagen. It shows that caffeine in its lower doses has stimulatory effect on growth and yield in Helianthus annuus L. while the higher doses have inhibitory effect and reduce the growth and yield upto some extent except number of seeds.
\end{abstract}

Keywords: Mutagenesis; Caffeine; Helianthus annuus L.

\section{Introduction}

Helianthus annuus L. (Family-Asteraecae) originated in south west United States Mexico area (Heiser 1976). Sunflower has considerable medicinal values. Leaves are reported to be employed in the treatment of malarial fever in Caucasus. The seeds of sunflower are diuretic and expectorant. They have been used in bronchial, laryngeal and pulmonary infections, cough and cold etc.

Caffeine (1, 3, 7-trimethylxanthine) is found in both coffee and tea, so a great number of people are exposed to various doses of caffeine. It acts as a stimulant for the central nervous, respiratory and cardiac system. Caffeine significantly reduces cancer risk caused by environmental and dietary carcinogens (Kesavan 2005) and the protective action of caffeine against a variety of chemical carcinogens was established by several studies, carried out by Abraham (1989 \& 1991). Because of purine nature it has a mutagenic potential. The mutagenic effect of caffeine was detected by Fries and Kihlman (1948) on Ophiostoma multiannulatum. Caffeine is an alkaloid which is found to be weakly mutagenic in bacterium $E$. coli, inducing back mutations (Gezelius and Fries 1952). It has been observed that caffeine also has the ability to act synergistically in inducing chromosomal aberrations in mammalian cells. Mutagens have remarkable possibilities of improving plants with regard to their quantitative and qualitative characters and mutagenic potential of caffeine has been tested in several plants by many workers (Kihlman 1974 \& 1976, Fries 1950, Cheng and Gao 1990, Anis and Wani 1997, Kumar and Tripathi 2004). The aim of this study is to investigate the effect of caffeine on growth and yield parameters in a member of family asteraecae, particularly in helianthus annuus $\mathrm{L}$.

\section{Materials and Methods}

Foundation, healthy seeds of Sunflower (Helianthus annuus L.) were presoaked in distilled water for 12 hours and were then subjected to nine different concentrations $(0.05 \%, 0.25 \%, 0.50 \%, 0.75 \%, 1.00 \%, 1.25 \%$, $1.50 \%, 1.75 \%$ and $2.00 \%$ ) of Caffeine solution, prepared in phosphate buffer of $\mathrm{pH}-7$ for 24 hours. One set of seeds was kept untreated to act as control. After completion of treatment period of 24 hours, seeds were thoroughly washed in running tap water to reduce the residual effects of mutagen sticking to the seed coat. Three replications of 50 -seeds each were sown for each treatment in pots to raise the $M_{1}$ generation. For measuring the seedling height, 10 selected seedlings were removed from the pots with an intense care out of entire population 
of each concentration and seedling height was calculated by the sum of root and shoot length.

\section{Statistical Analysis}

The experimental data were statistically analyzed using the analysis of variance techniques according to Gomez and Gomez (1984). In applying the F test, the error due to replicates was also determined. When the $F$ value was found to be significant at $1 \%$ and $5 \%$ level of probability, the least significant difference (LSD) was calculated.

\section{Results}

In present investigation, the average seedling height on $30^{\text {th }}$ day of sowing and average height of mature plant showed an increase over control upto some extent in lower concentrations (11.8, $11.10,11.5$ inches seedling height in $0.05 \%$, $0.25 \%, 0.5 \%$ and $47.7,45.3,45.1$ and 43.7 inches mature plant height in $0.05,0.25,0.5$ and
$0.75 \%$ of caffeine respectively, Table- 1 ) and then decrease to 9.1 inches in juvenile stage on $30^{\text {th }}$ day and 36.3 inches in mature plant in caffeine $(2 \%)$. However, the seedling height on $30^{\text {th }}$ day of sowing and mature plant height are 10.5 and 42.9 inches in control respectively. Majority of treated populations showed a longer life span over control (93 days) but in the last four doses $(1.25,1.50,1.75$ and $2 \%)$ of caffeine, the plants showed shorter life span viz. 90, 89, 80,77 days.

The yield of treated populations increased with increasing concentrations of caffeine as far as the number of seeds is concerned. A significant increase in the number of seeds is independent of the weight per hundred seeds. Although, there is an increasing trend in the weight hundred seeds in some concentrations (like 3.56, 3.66, 4.50, and 4.90 grams in $0.05 \%, 0.25 \%, 1.75 \%$ and $2.00 \%$ of caffeine respectively).

Table-1: Effect of Caffeine on some biological parameters in $\mathbf{M}_{1}$ generation of Helianthus annuus L. variety Modern (Mean of replicates with standard deviation).

\begin{tabular}{|c|c|c|c|c|c|c|c|}
\hline Concentrations & $\begin{array}{l}\text { Seedling height } \\
\text { on } 30^{\text {th }} \text { day of } \\
\text { sowing (in } \\
\text { inches) }\end{array}$ & $\begin{array}{c}\text { Seedling } \\
\text { height } \\
\text { injury (\%) }\end{array}$ & $\begin{array}{l}\text { Mature plant } \\
\text { height (in } \\
\text { inches) } \\
\text { Mean } \pm \text { S.D. }\end{array}$ & $\begin{array}{l}\text { Height } \\
\text { injury of } \\
\text { mature } \\
\text { plant (\%) }\end{array}$ & $\begin{array}{l}\text { Days to } \\
\text { maturity } \\
\text { Mean士S.D. }\end{array}$ & $\begin{array}{c}\text { No. of seeds } \\
\text { per plant } \\
\text { Mean } \pm \text { S.D. }\end{array}$ & $\begin{array}{c}\text { 100-seeds } \\
\text { Weight } \\
\text { (grams) } \\
\text { Mean } \pm \text { S.D. }\end{array}$ \\
\hline & Mean \pm S.D. & & & & & & \\
\hline Control & $10.5 \pm 1.39$ & & $42.9 \pm 3.72$ & - & $93 \pm 1.93$ & $370 \pm 9.04$ & $3.50 \pm 0.42$ \\
\hline $0.05 \%$ & $11.8^{* *} \pm 1.37$ & -12.38 & $47.7^{* \star} \pm 2.99$ & -11.19 & $96 \pm 2.22$ & $375 \pm 9.31$ & $3.56 \pm 0.43$ \\
\hline $0.25 \%$ & $11.10 \pm 1.62$ & -5.72 & $45.3 \pm 6.20$ & -5.59 & $100 \pm 2.31$ & $375 \pm 11.13$ & $3.66 \pm 0.44$ \\
\hline $0.50 \%$ & $11.5^{\star} \pm 1.19$ & -9.53 & $45.1 \pm 4.50$ & -5.13 & $114^{\star *} \pm 3.90$ & $390 \pm 12.90$ & $1.63^{\star *} \pm 0.20$ \\
\hline $0.75 \%$ & $10.5 \pm 1.39$ & 0.00 & $43.7 \pm 7.39$ & -1.87 & $110^{* *} \pm 3.75$ & $415 \pm 15.21$ & $1.73^{* *} \pm 0.23$ \\
\hline $1.00 \%$ & $9.5^{\star} \pm 1.54$ & +9.53 & $38.5^{\star} \pm 5.27$ & +10.26 & $101^{*} \pm 3.83$ & $418^{*} \pm 15.47$ & $2.57^{\star \star} \pm 0.33$ \\
\hline $1.25 \%$ & $8.9^{\star *} \pm 0.68$ & +15.24 & $35.7^{* \star} \pm 7.45$ & +16.78 & $90 \pm 2.87$ & $560^{\star \star} \pm 17.85$ & $2.26^{\star *} \pm 0.28$ \\
\hline $1.50 \%$ & $9.1^{* *} \pm 0.95$ & +13.34 & $36.1^{* *} \pm 6.81$ & +15.85 & $89 \pm 3.37$ & $712^{* *} \pm 16.17$ & $2.69^{* *} \pm 0.33$ \\
\hline $1.75 \%$ & $9.0^{* *} \pm 1.54$ & +14.29 & $36.1^{* *} \pm 4.69$ & +15.85 & $80^{* *} \pm 3.48$ & $869^{* *} \pm 16.32$ & $4.50^{* *} \pm 0.58$ \\
\hline $2.00 \%$ & $9.1^{\star \star} \pm 0.95$ & +13.34 & $36.3^{* *} \pm 2.36$ & +15.38 & $77^{* \star} \pm 5.33$ & $990^{* *} \pm 22.36$ & $4.90^{\star *} \pm 0.63$ \\
\hline LSD at $5 \%\left({ }^{*}\right)$ & 0.83 & & 3.35 & & 7.69 & 46.91 & 0.27 \\
\hline LSD at $1 \%\left({ }^{* *}\right)$ & 1.14 & & 4.59 & & 10.53 & 64.26 & 0.38 \\
\hline
\end{tabular}




\section{Discussion}

The average seedling height on $30^{\text {th }}$ day of sowing and mature plant height exhibited an increase over control upto some extent in lower doses and then a decrease with the increasing concentrations of caffeine. Seedling height on $30^{\text {th }}$ day of sowing and at maturity was studied to compare the toxic effect of caffeine in the form height injury. However, the study reveals a slight increase in the percentage of height injury at maturity in higher doses. It indicates that toxic effect of a chemical mutagen on plant height may be understood well at maturity as compare to juvenile stage.

Caffeine treatment in the enhancement of seedling growth at lower concentrations is quite similar to that of lower doses of DES and 2, 4-D as observed by Siddiqui et al. (1980). The low concentrations of caffeine cause low toxicity and probably act as growth regulator and hence height increased over control as observed in case of lower concentrations of EDTA in maize (Kiril 1980). Caffeine showed a stimulatory effect on plant height at lower doses in Capsicum annuum L. while higher doses were found inhibitory (Kumar and Tripathi 2004).

The most probable causes for reduced seedling growth are suggested to be uneven damage to meristematic cells as a consequence of genetic injuries (Gray and Scholes 1951), structural changes in the constitution of chromosome (Thoday 1951). Sparrow et al. (1958) reported that reduced stem elongation is due to reduced nutrition contents and the mechanism of assimilation may also be important factor. Similar results have been observed by Cheng and Gao (1988) in barley, by Krishna et al. (1984) in Chloris gayana Kunth. Remarkable height injury has been observed by chemical mutagens in several crops (Reddy 2001, Nobipour et al. 2004, Stamo 2007).

The delaying effect of mutagen in maturity on treated plants as observed in Helianthus annuus L. was also observed in Zea mays (Kaushik and Sharma 1974).

Reduction in yield components was observed in gamma ray irradiated caraway plants while, induced increase in yield components for both fennel and black cumin (Khalil 2001). Successful development of useful mutants with improved early seed maturity, coupled with high seed yield, seed quality and determinate growth habit have been reported by EMS treatments (Basu et al. 2007). Medium or moderate doses of gamma rays under dry treatment and higher doses under soaked treatment were found more effective to inducing genetic variability for grain yield and its attributing characters in blackgram [Vigna mungo L. Hepper] (Kumar and Mishra, 2006). Decreased yield has been observed in different crops by several mutagens (Brock and Latter 1961, Scossiroli 1964, Gaul 1969). Zeerak (1990) observed reduced yield in combined treatments of gamma rays and EMS in Solanum melongena L. Remarkable loss in yield has been experienced by chemical mutagens in soybean (Pavadai and Dhanvel 2004), bread wheat (Varshney 1997). Reduction in yield by both physical and chemical mutagens has been reported in cowpea (Banu et al. 2005), soybean (Karthika and Lakshmi 2006).

It may be concluded that these morphological variations may be due to physiological disturbances and some disturbances at genetic level like chromosomal damage disturbed chromosomal coiling, failure or restricted pairing etc. by the action of caffeine and all these lead to mutations and selection of desired characters. Caffeine in its higher doses may be inhibitory cum toxic for plant growth and yield but further researches are needed to confirm this fact, so according to Paracelsus (1493-15-41), philosopher and father of modern technology, only the dose determines that a thing is not poison in a world where all things are poison, and none without poison.

\section{Acknowledgements}

The authors are thankful to Chairman, Department of Botany, Aligarh Muslim University, Aligarh to provide necessary facilities for the completion of this work and one of the authors, Mr. Danish Shahab is also thankful to University Grant Commission (UGC), New Delhi for providing financial assistance.

\section{References}

Abraham, S.K., 1989. Inhibition of in vivo genotoxicity by coffee. Food and Chemical Toxicology, 27: 787792.

Abraham, S.K., 1991. Inhibitory effects of coffee on the genotoxicity of carcinogens in mice. Mutation Research, 262: 109-114.

Anis, M., Wani, A.A., 1997. Caffeine induced morphocytological variability in Fenugreek, Trigonella foenum-graecum L. Cytologia, 62: 343-349. 
Banu, M.R., Kalamani, A., Ashok, S., Makesh, S., 2005. Effect of mutagenic treatments on quantitative characters in $\mathrm{M}_{1}$ generation of cowpea (Vigna unguiculata (L.) Walp). Advances in Plant Sciences, 18(2): $505-510$

Basu, S. K., Acharya, S.N., Thomas, J.E., 2007. Genetic improvement of fenugreek (Trigonella foenum-graecum L.) through EMS induced mutation breeding for higher seed yield under western Canada prairie conditions. Euphytica DOI 10.1007/s10681007/9545-9.

Brock, Latter, B.D.H., 1961. Radiation induced quantitative variation in subterranean clover. Proceeding of $3^{\text {rd }}$ Australian Conference on Radiobiology, pp: 205-215.

Cheng, X.Y., Gao, M.W., 1988. Biological and genetic effects of combined treatments of sodium azide, gamma rays and EMS in barley. Environmental and Experimental Botany, 28: 281-288.

Cheng, X.Y., Gao, M.W., 1990. Enhancement of sodium azide mutagenesis by caffeine in barley (Hordeum vulgare L.). Journal of Genetics and Plant Breeding, 44: 157-161.

Fries, N., Kihlman, B., 1948. Fungal mutations obtained with methyl xanthines. Nature, 162: 573.

Fries, N., 1950. The production of mutations by caffeine. Hereditas, 36: 134-150.

*Gaul, H., 1969. Mutation inderzuetung von selbstbestaubenden Getreidearten, Vortage Fur. Pflanzenzuchter, DLG. Verlag, Frankfurt Main., 12: 234.

Gezelius, K, Fries, N., 1952. Phage resistance mutants induced in $E$. coli by caffeine. Heriditas, 38: 112.

Gray, L.H., Scholes, M.E., 1951. The effect of ionizing radiations on the broad bean roots. VIII. Growth rate studies and histological analysis. British Journal of Radiology, 24: 82-92.

Heiser, C.B., 1976. The Sunflower. University of Oklahoma Press, USA.

Karthika, R., Lakshmi, B.S., 2006. Effect of gamma rays and EMS on two varieties of soybean. Asian Journal of Plant Science, 5(4): 721-724.

Kaushik, M.P., Sharma, J.K., 1974. Effects of gamma irradiations of seeds on sex modification in Zea mays L. Geobios, 1: 27-28.
Kesavan, P.C., 2005. Oxygen effect in radiation biology: Caffeien and serendipity. Current Science, 89(2): 318-328.

Khalil, M.Y., El-Sherbeny, S.E., HUSSEIN, M.S., 2001. Growth, yield and chemical constituents of some medicinal plants in relation to gamma irradiation. Egyptian Journal of Horticulture, 28(3): 355-369.

Kihlman, B.A., 1974. Effect of caffeine on the genetic material. Mutation Research, 26: 53-71.

Kihlman, B.A., 1976. Action of chemical on dividing cells. Prentice Hall, Inc.

Kiril, K., 1980. Mutagenic effect of chemical mutagens in solution or gas phase in seed. Genetics Selection Evolution, 13: 247-257.

Krishna, G., Shivashankar, G., Nath, J., 1984. Mutagenic response of Rhodes grass (Chloris gayana Kunth) to gamma rays. Environmental and Experimental Botany, 24: 197-205.

Kumar, A., Mishra, M.N., 2006. Studies on genetic variability induced by gamma rays in $\mathrm{M}_{2}$ population of blackgram (Vigna mungo L. Hepper). Advances in Plant Sciences, 19(1): 263-266.

Kumar, G., Tripathi, A., 2004. Mutagenic response of caffeine in Capsicum annuum L. Journal of Indian Botanical Society, 83: 136-140.

Nabipour, A., Yazdi-Samadi, B., sarrafi, A., 2004. Genetic control of some morphological mutant in sunflower. Journal of Genetics and Plant Breeding, 58(2): 157-162.

Pavadai, P., Dhanavel, D., 2004. Effect of EMS, DES and colchicine treatment in soybean. Crop Research, 28 (1-3): 118-120.

Reddy, V.R.K., 2001. Polygenic variability for various quantitative characters in some cereal crops. Advances in Plant Sciences, 14(2): 331-334.

Scossiroli, R.E., 1964. Effectiveness of artificial selection under radiation of plateued population of Drosophilla melangogaster. Symposium on Genetics and Population Structure, USSB Publication, 15: 4266.

Siddiqui, S. A., Ahmad, R., Ansari, M.Y.K., 1980. Studies on the effect of DES and 2, 4-D in Helianthus annuus L. Plant Science, 12: 7-11.

Sparrow, A.H., Binnington, J.P., Pond, V., 1958. Bibliography in the effect of ionizing radiation on plants 1896 to 1955. Brookhavan National Laboratory Upton, New York. 
Stamo, I., Ylli, A., Dodbiba, A., 2007. Induced mutations for improving production on bread and durum wheat. AIP Conference Proceeding, pp: 747.

Thoday, J.M., 1951. The effect of ionizing radiations on the broad bean root part IX. Chromosome breakage and the lethality of ionizing radiation to root meristem. British Journal of Radiology, 24: 572-576.
Varshney, R.A., Siddiqui, B.A., 1997. Effects of thiourea in $M_{1}$ generation of bread wheat (Triticum aestivum I.). Journal of Indian Botanical Society, 76: 165-168.

Zeerak, N.A., 1990. Induced morphological variants in Brinjal (Solanum melongena L.). Phytomorphology, 40(3\&4): 251-256.

*Original not seen 